\title{
The Effects of Repetitive Greater Occipital Nerve Blocks on Cervicogenic Headache
} Tekrarlayıcı Büyük Oksipital Sinir Bloklarının Servikojenik Baş A ğrısında Etkileri

\author{
(1) Devrimsel Harika Ertem ${ }^{1}$, ๑ İlhan Y1lmaz² \\ 1 University of Health Sciences, Istanbul Sisli Hamidiye Etfal Training and Research Hospital, Clinic of Algology, Istanbul, Turkey \\ 2University of Health Sciences, Istanbul Sisli Hamidiye Etfal Training and Research Hospital, Clinic of Neurosurgery, Istanbul, Turkey
}

\begin{abstract}
Objective: The clinical features of cervicogenic headache $(\mathrm{CH})$ are characterized by unilateral, dull headache; precipitated by neck movements or external pressure over the great occipital nerve (GON). No conservative therapies have been proved to be effective for the management of $\mathrm{CH}$. The purpose of this study was to assess the effects of interventional pain management, including repetitive anesthetic block using lidocaine and methylprednisolone GON injections for local pain and associated headache.

Materials and Methods: This retrospective cohort study was undertaken between January 2016 and December 2017. Twenty-one patients with CH were evaluated in our headache clinic during the study period. The diagnosis of $\mathrm{CH}$ was made according to International Classification of Headache Disorders $3^{\text {rd }}$ edition beta version. The socio-demographic and clinical characteristics were recorded for all patients who underwent at least 3 GON blocks and attended at least 4 follow-up appointments. Change in the Numeric Pain Rating Scale (NPRS) was used to assess the response to GON blocks. SPSS 23.0 was used as the statistical analysis program.

Results: The mean age of patients was $61.51 \pm 13.88$ years; $42.85 \%$ were female. The duration of headache was $30.81 \pm 21.95$ years. Eighty-five percent of patients had unilateral headache. Ten patients had myofascial spasm (trigger points) located in neck, occipitalis, and temporalis muscles. Sixty-six percent of patients reported headache following head trauma. From 3-months post treatment, a significant decrease in NPRS $(\mathrm{p}<0.001)$ was identified. The number of headaches was reduced significantly at three months $(\mathrm{p}<0.001)$ No serious complications were noted. The coexistence of myofascial spasms, history of trauma and additional headache had no significant effect on NPRS score improvements ( $\mathrm{p}>0.05)$.

Conclusion: The results of this study demonstrated that repetitive greater occipital blocks may be an effective option for the management of $\mathrm{CH}$ and contribute to significant reductions in pain severity scores at 3 months following injection.
\end{abstract}

Keywords: Headache, cervicogenic headache, chronic pain, greater occipital nerve, nerve block

$\ddot{\mathbf{O z}}$

Amaç: Servikojenik baş ağrısının "cervicogenic headache" $(\mathrm{CH})$ klinik özellikleri tek taraflı, dolgun baş ağrısıyla karakterizedir; boyun hareketleri veya büyük oksipital sinir üzerine basınç ile provoke edilir. CH’nin tedavisinde etkili bir konservatif yöntem tanımlanmamıştır. Bu çalışmanın amacı, CH’da büyük oksipital sinire tekrarlayıc lidokain ve metilprednizolon enjeksiyonlarının girişimsel ağrı tedavisinde etkilerini değerlendirmektir.

Gereç ve Yöntem: Bu retrospektif kohort çalışması Ocak 2016 ile Aralık 2017 tarihleri arasında yapıldı. Çalışma dönemi boyunca baş ağrısı polikliniğgimizden takip edilen yirmi bir hasta değerlendirildi. CH tanısı, Uluslararası Baş Ağrısı Bozuklukları 3. baskı beta versiyonuna göre yapıldı. En az 3 büyük oksipital sinir blok geçiren ve en az 4 takip randevusuna katılan tüm hastalar için sosyo-demografik ve klinik özellikler kaydedildi. Büyük oksipital sinir bloklarına cevabı değerlendirmek için Sayısal A ğrı Derecelendirme Ölçeğìnde (NPRS) değişim kullanıldı. İstatistiksel analiz programı olarak SPSS 23.0 kullanıldı.

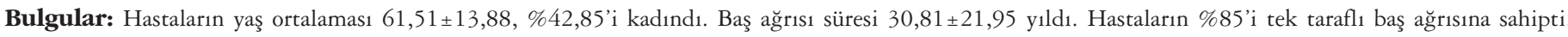
On hastada boyun, oksipital ve temporalis kaslarında miyofasiyal spazm (tetik noktalar) vardı. Hastaların \%61'i kafa travması sonrası baş ağrısını bildirmişti. Tedaviden 3 ay sonra NPRS'de anlamlı bir azalma $(\mathrm{p}=0,000)$ tespit edildi. Baş ağrisı sayısı üç ayda belirgin olarak azaldı $(\mathrm{p}=0,000)$. Ciddi bir komplikasyon görülmedi. Miyofasiyal spazmlar, travma öyküsü ve ek baş ağrısının birlikteliği, NPRS skorlarının düzelmesinde önemli bir etkiye sahip olmadı (p>0,05).

Sonuç: Bu çalışmanın sonuçları, tekrarlayan büyük oksipital sinir blokların, $\mathrm{CH}$ tedavisinde etkili bir seçenek olabileceğini ve enjeksiyondan sonraki 3 ay içinde ağrı şiddeti skorlarında anlamlı azalmaya neden olduğunu göstermektedir.

Anahtar Kelimeler: Baş ağrısı, servikojenik baş ağrısı, kronik ağrı, büyük oksipital sinir, sinir bloğu

Address for Correspondence/Yazışma Adresi: Devrimsel Harika Ertem MD, University of Health Sciences, Sisli Hamidiye Etfal Training and Research Hospital, Clinic of Algology, Istanbul, Turkey

Phone: +90 5301428876 E-mail: hkaozhan@gmail.com ORCID ID: orcid.org/0000-0001-5309-1258

Received/Geliş Tarihi: 29.08.2018 Accepted/Kabul Tarihi: 17.09.2018

${ }^{\circ}$ Copyright 2019 by Turkish Neurological Society

Turkish Journal of Neurology published by Galenos Publishing House. 


\section{Introduction}

Cervicogenic headache $(\mathrm{CH})$ implies a chronic hemicranial pain caused by a disorder of the cervical spine and its anatomic structures innervated by the $\mathrm{C} 1, \mathrm{C} 2$, and $\mathrm{C} 3$ cervical spinal nerves (1). According to The International Classification of Headache Disorders, $3^{\text {rd }}$ edition (beta version), the diagnostic criteria of $\mathrm{CH}$ are as follows: evidence of a disorder or lesion within the cervical spine or soft tissues of the neck, pain developed in temporal relation to the onset of the cervical disorder and improvement after treatment of the cervical disorder, reduced cervical range of motion, worsening by provoking, and pain relief following diagnostic blocks (2).

$\mathrm{CH}$ is generally associated with head or neck injury, but may also occur without trauma.

Symptoms of $\mathrm{CH}$ are typically dull and radiating occipital or neck pain; local tenderness with pressure over suboccipital area; painful rotation of cervical spine, and restricted active and passive neck range of motion; and pain provocation with passive rotation of neck (3). Although the clinical features of $\mathrm{CH}$ have not been validated for diagnosis, diagnostic blocks targeting the greater and lesser occipital nerves from the dorsal ramus of $\mathrm{C} 2$ and $\mathrm{C} 3$ can be both diagnostic and therapeutic (4). No oral medications have been shown to be effective for the treatment of $\mathrm{CH}$. Physical treatment modalities such as muscle stretching and manual cervical traction have been studied for headache of cervical origin, but much of the published literature consists of case reports or case series (5). When conservative treatment fails, interventional pain management methods, including injection of local anesthetics and corticosteroid at the location of great occipital nerve (GON), intraarticular/medial branch corticosteroid injection (C2-3, C3-4 zygapophysial joints, medial branches of the $\mathrm{C} 3$ and $\mathrm{C} 4$ dorsal rami), radiofrequency ablation (RFA), occipital nerve stimulation, epidural steroid injections, and surgical treatment are other options for the treatment of $\mathrm{CH}(5,6)$.

Early studies including different types of study designs reported an improved control of $\mathrm{CH}$ pain after $\mathrm{GON}$ blocks $(6,7,8)$. To date, however, there are no similarly well-known GON injection protocols for the treatment of $\mathrm{CH}$. The aim of this study was to assess the efficacy and long-lasting response of repeat GON injections using corticosteroid and local anesthetics in the treatment of $\mathrm{CH}$.

\section{Materials and Methods}

\section{Participants}

This retrospective cross-sectional study was approved by the Ethics Committee of Istanbul Sisli Hamidiye Etfal Training and Research Hospital (protocol number: 1889, date: 06/02/2018) and was performed in accordance with the Declaration of Helsinki. Twenty-two patients, having undergone at least 3 GON blocks and attended at least 3 follow-up appointments for the treatment of $\mathrm{CH}$, and were admitted to our headache clinic during a 6-month period from June 2017 to December 2017 were evaluated. Patients with secondary headaches, psychiatric disorders, organic disease of the brain or spinal cord, cancer, and coagulopathy were excluded. All patients were diagnosed as having $\mathrm{CH}$ according to International Classification of Headache Disorders $3^{\text {rd }}$ edition beta version criteria (2). Diagnosis of $\mathrm{CH}$ was made on the basis of headache history, physical motion examination, pressure points, and imaging studies of cervical structures to exclude other medical conditions.

The patients' demographic characteristics (age, sex), onset of headache, additional primary headaches, pain due to active myofascial trigger points, headache days per month, history of trauma, neurologic examinations, and post-injection complications were recorded. Change of pain severity in the Numeric Pain Rating Scale (NPRS) was used to assess the response to GON blocks.

\section{Injection Procedure}

The GON on the scalp, located at the upper part of the neck, was found to be approximately $10-15 \mathrm{~mm}$ medial to the midpoint of the line of the occipital tubercle and the mastoid tip on the headache side. A mixture of local anesthetic $3-4 \mathrm{~mL}$ of $2 \%$ lidocaine and $1 \mathrm{~mL}$ of methylprednisolone acetate was injected at the site.

\section{Statistical Analysis}

SPSS 23.0 was used as the statistical analysis program. Descriptive statistics (mean, standard deviation, frequency, and percentage) were used for the demographic and clinical characteristics. The analysis of variance (ANOVA) with repeated measures test was used to compare follow-up NPRS scores. Categorical data were compared using the chi-square test or Fisher's exact test. A p value of $<0.05$ was considered to be statistically significant.

\section{Results}

Of the 21 patients (mean age $61.51 \pm 13.88$ years; range, 32-84 years; 12 males), details of demographic and headache characteristics of the study group is given in Table 1. All patients reported that they had tried oral medical treatments, such as

\begin{tabular}{|ll|}
\hline $\begin{array}{l}\text { Table 1. Demographic and clinical characteristics of the } \\
\text { patients }\end{array}$ & Number of patients (n) \\
$\begin{array}{l}\text { Characteristics of } \\
\text { patients }\end{array}$ & $9 / 12$ \\
Sex (F/M) & $61.51 \pm 13.88$ (range, 32-84) years \\
Age & $30.81 \pm 21.95$ (range, 6-72) months \\
$\begin{array}{l}\text { Duration (month) } \\
\text { Number of headache days }\end{array}$ & $21.10 \pm 5.07$ days \\
monthly & \\
$\begin{array}{l}\text { Localization } \\
\text { Right }\end{array}$ & $\mathrm{n}=11(52.4 \%)$ \\
$\begin{array}{l}\text { Left } \\
\text { Bilateral }\end{array}$ & $\mathrm{n}=3(14.3 \%)$ \\
Myofascial spasm & $\mathrm{n}=10(47.6 \%)$ \\
History of trauma & $\mathrm{n}=14(66.7 \%)$ \\
$\begin{array}{l}\text { Additional headache } \\
\text { Migraine }\end{array}$ & $\mathrm{n}=7(33.3 \%)$ \\
Tension-type & $\mathrm{n}=2$ \\
Initial NPRS scores & $\mathrm{n}=5$ \\
F/M: Female/Male, NPRS: Numeric Pain Rating Scale \\
\hline
\end{tabular}


paracetamol, non-steroidal anti-inflammatory drugs, and/or topical analgesic creams before admission. Onset of headache was $30.81 \pm 21.95$ months and the mean number of headache days per month was $21.10 \pm 5.07$. Eighteen patients $(85.7 \%)$ had unilateral headache and $52.4 \%$ of patients had right-sided $\mathrm{CH}$. Headache was most frequently located in the neck, occipital, temporal, and frontal areas. Ten $(47.6 \%)$ patients had myofascial spasm (trigger points) located in the trapezius, levator scapulae, splenius capitiis, semispinalis, and temporalis muscles. Headache following head trauma was reported by $66.7 \%$ of patients. Seven (33.3\%) patients had additional primary headaches. Five patients had tension-type headache and 2 patients had episodic migraine.

The mean NPRS scores before and after injection were $6.71 \pm 0.64$ and $1.48 \pm 0.93$, respectively, with a significant decline $(\mathrm{p}<0.001)$. The mean NPRS scores were recorded as follows for the first month (second injection) and second month (third injection): $3.52 \pm 1.21,2.38 \pm 1.40$, respectively. Eight patients reported that they had no pain so they did not receive their fourth injection. The mean NPRS scores of the third month (fourth injection) of the other 13 patients was $1.71 \pm 1.59$. For analyzing the mid-term effect of injections on NPRS scores, the ANOVA with repeated measures test was used (Table 2). This difference was noted to be statistically significant $(\mathrm{p}<0.001)$. The mean number of headache days declined to $3.40 \pm 1.20$ in the third month $(\mathrm{p}<0.001)$.

Two-way ANOVA with repeated measures was applied to analyze the effects of clinical characteristics, such as myofascial spasms, history of trauma, and additional primary headaches (migraine or tension-type headache). The coexistence of myofascial spasms $(p=0.191)$, history of trauma $(p=0.810)$, and additional headache $(\mathrm{p}=0.280)$ had no significant effect on the improvement of NPRS scores.

Most post-injection complications were minor and transient. The complications were as follows: increased pain during injection day, temporary numbness, pain at injection site. Infection, hematoma, paralysis, and nerve root injury were not reported.

\section{Discussion}

This study aimed to demonstrate outcomes pertaining to the management of $\mathrm{CH}$ after performing repeat GON injections using corticosteroid and local anesthetics over a three-month period. After treatment, a decline of the initial NPRS scores and the mean number of headache days were noted to be statistically significant.

\begin{tabular}{|c|c|c|c|}
\hline & $\begin{array}{l}\text { Mean } \\
\text { NPRS } \\
\text { scores }\end{array}$ & $\begin{array}{l}\text { Mean NPRS } \\
\text { difference } \\
\text { from previous } \\
\text { period }\end{array}$ & $\begin{array}{l}\mathrm{p} \\
\text { value }\end{array}$ \\
\hline $\begin{array}{l}\text { First month (before } \\
\text { the second injection) }\end{array}$ & $3.52 \pm 1.21$ & $-3.19(-47.5 \%)$ & $<0.001$ \\
\hline $\begin{array}{l}\text { Second month (before } \\
\text { the third injection) }\end{array}$ & $2.38 \pm 1.40$ & $-1.14(-32.4 \%)$ & 0.001 \\
\hline $\begin{array}{l}\text { Third month (before } \\
\text { the fourth injection) }\end{array}$ & $1.71 \pm 1.59$ & $-0.67(-28.2 \%)$ & 0.027 \\
\hline \multicolumn{4}{|l|}{ NPRS: Numeric Pain Rating Scale } \\
\hline
\end{tabular}

Furthermore, coexistence of trigger points of myofascial spasms, history of trauma, and additional primary headaches (migraine or tension-type headache) showed no association with the severity of pain during the procedures.

Although the exact pathophysiology of $\mathrm{CH}$ is not clear, headache related to cervical spine structures are potential sources of neck and occipital pain. The mechanism of $\mathrm{CH}$ has been explained by the convergence between cervical and trigeminal afferents in the dorsal horn of the $\mathrm{C} 1-3$ cervical segments of the spinal cord. The third occipital nerve innervates the $\mathrm{C} 2-\mathrm{C} 3$ cervical facet joints and this is the most common source of $\mathrm{CH}$. The $\mathrm{C} 2-\mathrm{C} 3$ cervical intervertebral disc, the atlantooccipital joint, and the $\mathrm{C} 3-\mathrm{C} 4$ facet joint also can cause $\mathrm{CH}(9,10)$. These joints and occipital nerve are the most vulnerable to trauma from whiplash of the neck. According to The ICHD-3 beta, headaches caused by head and neck trauma are classified separately. For this reason, trauma is not necessarily the cause of $\mathrm{CH}$. Only $66.7 \%$ of our sample reported a history of trauma, and we found that the decline of pain severity scores did not differ from patients who had no trauma during the treatment.

The differential diagnosis for $\mathrm{CH}$ includes a wide variety of medical disorders, such as the following: posterior fossa or spinal tumors, developmental anomalies of the craniocervical junction (Arnold Chiari type 1 malformation), osteomyelitis of the cervical vertebrae, rheumatoid arthritis, ankylosing spondylitis, traumatic subluxation of the upper cervical vertebrae, cervical herniated intervertebral disc, cervical spondylosis or arthropathy, spinal nerve compression, and vertebral artery dissection (4). The ICHD3 beta states that demonstration of clinical signs of pain in the neck and abolition of headache following diagnostic blockade of a cervical structure or its nerve are evidence that the neck pain can be attributed to $\mathrm{CH}$. The patients included in this study were diagnosed according to the ICHD-3 beta. All of our patients had a dramatic pain relief after the first injection to the GON.

Provocation of headache by pressure on neck muscles and radiation of pain are some of the main characteristics of $\mathrm{CH}$. $\mathrm{CH}$ can present with different clinical features and symptoms because the cervicotrigeminal connections may refer to pain impulses from the neck to the frontotemporal region (11). Cervical myofascial trigger points have been reported as a cause of $\mathrm{CH}$, but there are no controlled studies yet (5). Of our sample, $47.6 \%$ had myofascial trigger points. Even though the decline of pain severity scores did not differ significantly from patients who had no cervical myofascial pain during the treatment, patients with trigger points reported that injections targeting these trigger points helped in their head movements and reduced side-locked pain. Physical examination of patients with $\mathrm{CH}$ should include an assessment of trigger points. We recommend routine trigger point examinations and injections for the successful pain management of $\mathrm{CH}$.

The treatment of patients with $\mathrm{CH}$ requires a generalized approach with pharmacologic, physical, and interventional pain management, including anesthetic block, zygapophysial joint/ medial branch corticosteroid injection, RFA, and surgical treatment (12). The benefits of physical treatments, cervical epidural steroid injections, and botulinum toxin for the treatment of $\mathrm{CH}$ have been reported previously $(13,14,15)$. Prior studies relating to the treatment of $\mathrm{CH}$ have shown that local steroid injection for $\mathrm{CH}$ are effective $(6,7,8,16)$. Despite the fact that injection of steroid in 
the GON is a valid and less destructive interventional treatment option, definitive evidence is lacking.

There are limited number of randomized controlled trials exploring the dose-response relationship and efficacy of blocking GON with local anesthetics and steroid injection for the treatment of $\mathrm{CH}$. Naja et al. (6) performed a randomized, double-blind, placebo-controlled trial to compare the effectiveness of nerve stimulator-guided occipital nerve block in the treatment of $\mathrm{CH}$ using anesthetic mixture of lidocaine $2 \%$ and bupivacaine $0.5 \%$ or normal saline as placebo on clinical improvement for two weeks. They reported that the decrease of pain severity and associated symptoms such as analgesic consumption, duration of headache and its frequency, nausea, vomiting, photophobia, phonophobia, and limitations in functional activities were statistically significant in the treatment group, but not in the placebo group. Patients were followed for two weeks after the injection, so the long-term effects of the injection have not been observed. Inan et al. (7) suggested that repeated GON blocks provided efficacy similar to repeated $\mathrm{C} 2 / \mathrm{C} 3$ blocks. We started with occipital nerve block to test for this condition. If the block responded positively, the patient was treated with repeated GON blocks with lidocaine and methylprednisolone once per month for three months. After 3 -months post-injections, nearly $40 \%$ of patients were pain free. Our findings support the results of İnan et al. (7).

The signs and symptoms of the primary headache disorders such as tension-type headache, migraine, or hemicrania continua may mimic the clinical features of $\mathrm{CH}$. Distinguishing $\mathrm{CH}$ from other types of headaches can be difficult. Moreover, some patients may present with different types of primary headaches. Anthony examined the prevalence of $\mathrm{CH}$ among patients with primary headache, and the effects of local corticosteroids into the region of the GON and lesser occipital nerve (13). Among 796 patients with primary headache, $16.1 \%$ were found to have $\mathrm{CH}$ and $20.1 \%$ had migraine plus $\mathrm{CH}$. Patients received $4 \mathrm{~mL} 1 \%$ lidocaine and $160 \mathrm{mg}$ methylprednisolone. The investigator concluded that injections of depot methylprednisolone into the region of the GON and $\mathrm{LON}$ for both $\mathrm{CH}$ and migraine plus $\mathrm{CH}$ groups produced complete pain relief for a period ranging from 10 to 77 days. Our work differs from this study in a few ways. First, in Anthony's study, the definitions of headaches were defined according to those of the 1988 International Headache Society Classification. Secondly, we performed repeated injections monthly with the aim of blocking the cervicotrigeminal circuit. In our sample, $33.3 \%$ of patients had additional primary headaches such as migraine and tension-type headache. Performing GON blocks was not associated with improved outcome in patients with additional headache. Our findings require confirmation in a larger sample study.

In our sample, most post-injection complications were minor and transient. However, due to blind injections, there is a risk of serious complications such as infection, hematoma, paralysis, and nerve root injury. For this reason, we highly recommend that these procedures should be performed by experienced physicians.

\section{Study Limitations}

The lack of a control group is a major limitation in our study. The use of a placebo control in any neural intervention is a difficult task, adding to ethical issues and difficulty with recruitment. In addition to these, because of the subjective nature of NPRS scores, pain experienced by patients during the treatment period might not be reflected objectively. Although the small sample size of patients with a relatively short follow-up duration limits the significance of our results, we conclude that GON blocks with a mixture of lidocaine and methylprednisolone for the treatment of $\mathrm{CH}$ is a safe, simple, and effective technique without severe adverse effects.

\section{Conclusion}

$\mathrm{CH}$ is a complex medical condition that can be challenging for physicians. Repeated GON injections may be considered as a useful treatment option for patients with $\mathrm{CH}$ for whom conservative treatments have failed because of the heterogeneity of interventional techniques for the treatment of $\mathrm{CH}$.

\section{Acknowledgments}

The authors thank Mr. Mustafa Cem Ertem for his assistance with statistical analysis.

\section{Ethics}

Ethics Committee Approval: This retrospective crosssectional study was approved by the Ethics Committee of Istanbul Sisli Hamidiye Etfal Training and Research Hospital (protocol number: 1889, date: 06/02/2018) and was performed in accordance with the Declaration of Helsinki.

Informed Consent: Consent form was filled out by all participants.

Peer-review: Internally peer-reviewed.

\section{Authorship Contributions}

Surgical and Medical Practices: D.H.E., İ.Y., Concept: D.H.E., Design: D.H.E., Data Collection or Processing: D.H.E., I.Y., Analysis or Interpretation: D.H.E., Literature Search: D.H.E., İ.Y., Writing: D.H.E.

Conflict of Interest: No conflict of interest was declared by the authors.

Financial Disclosure: The authors declared that this study received no financial support.

\section{References}

1. Fredriksen TA, Antonaci F, Sjaastad O. Cervicogenic headache: too important to be left un-diagnosed. J Headache Pain 2015;16:6.

2. Headache Classification Committee of the International Headache Society (IHS). The International Classification of Headache Disorders 3rd edition (beta version) ICHD-3 beta. Cephalalgia 2013;33:629-808.

3. Bogduk N. The neck and headache. Neurol Clin 2004;22:151-171.

4. Biondi DM. Cervicogenic headache: a review of diagnostic and treatment strategies. J Am Osteopath Assoc 2005;105:16-22.

5. Bogduk N. The Neck and Headaches. Neurol Clin 2014;32:471-487.

6. Naja ZM, El-Rajab M, Al-Tannir MA, Ziade FM, Tawfik OM. Occipital nerve blockade for cervicogenic headache: a double-blind randomized controlled clinical trial. Pain Pract 2006;6:89-95.

7. İnan $\mathrm{N}$, Ceyhan $\mathrm{A}$, İnan $\mathrm{L}$, et al. $\mathrm{C} 2 / \mathrm{C} 3$ nerve blocks and greater occipital nerve block in cervicogenic headache treatment. Funct Neurol 2001;16:239243.

8. Lauretti GR, Correa SW, Mattos AL. Efficacy of the Greater Occipital Nerve Block for Cervicogenic Headache: Comparing Classical and Subcompartmental Techniques. Pain Pract 2015;15:654-661.

9. Zhang J, Shi DS, Wang R. Pulsed radiofrequency of the second cervical ganglion (C2) for the treatment of cervicogenic headache. J Headache Pain 2011;12:569-571. 
10. Becker WJ. Cervicogenic headache: evidence that the neck is a pain generator Headache 2010;50:699-705.

11. Lance JW, Goadsby PJ. Mechanism and management of headache. 6th ed. Boston: Butterworth-Heinemann, 1998.

12. Bogduk N, Govind J. Cervicogenic headache: an assessment of the evidence on clinical diagnosis, invasive tests, and treatment. Lancet Neurol 2009;8:959-968.

13. Biondi D. Physical treatments for headache: a structured review. Headache. 2005; $45: 1-9$
14. Wang E, Wang D. Treatment of Cervicogenic Headache with Cervical EpiduralSteroid Injection. Curr Pain Headache Rep 2014;18:442.

15. Karadaş Ö, Öztürk B, Zincir S, et al. Anxiety and depression levels in cervicogenic headache patients before and after botulinum toxin A treatment. Bulletin of Clinical Psychopharmacology 2011;21:232-236.

16. Anthony M. Cervicogenic headache: prevalence and response to local steroid therapy. Clin Exp Rheumatol 2000;18:59-64. 